\title{
METODE PENURUNAN RESPON DINAMIK SISTEM POROS-ROTOR DENGAN PEREDAM VISCOUS ROTARY
}

\author{
Nusyirwan \\ Jurusan Teknik Mesin, Fakultas Teknik Universitas Andalas Padang \\ e-mail: nusyirwan@ft.unand.ac.id,nusyirwan@gmail.com
}

\begin{abstract}
Viscosity or viscosity is one of the quantities that are very important in the analysis of the behavior and movement of fluids that come into contact with other objects such as solids \{solid body). Viscous dampers can be used to reduce the amplitude of the response due to the unbalanced mass, rotation critically, noise and shock loads. Absorbers working with fluid film bearing securities which are placed at a certain point, which is connected to the shaft-rotating rotor. Certain viscosity fluid will be forced to pass through a narrow slit with a certain pressure that can absorb the energy supplied by the shaft, this damping effects that can provide resistance to the rotor shaft system because the fluid has a linear damping and damping effect histeriktik. Viscous dampers can be used to reduce vibration amplitude response at a fixed price in accordance with the physical nature of the damper, the use of viscous dampers are widely used to control engine speed and turbine rotational speeds are like a helicopter rotor. From the test we can produce the damping effect on the engine rotation can reduce the response time domain vibration with an amplitude reduction of approximately $60 \%$ for the damping ratio $\zeta=0.5$.
\end{abstract}

Keyword: viscosity, solid body, shock loads, fluid film, absorber, damping effect, histeriktik

\section{PENDAHULUAN}

\section{Latar Belakang}

Efek redaman terjadi karena adanya gerakan relatif antara dua permukaan benda yang bersifat padat (solid body) dengan fluida yang bersifat viskos, yang akan menyebabkan terjadinya gaya seret (drag force). Gaya seret adalah gaya yang bekerja akibat tekanan fluida terhadap benda padat dan paralel dengan arah gerakan dan sebanding dengan luas perrmukaan benda.

Pada sistem yang mengalami getaran, efek seretan oleh fluida viscos dapat dimanfaatkan untuk mengurangi getaran yang terjadi akibat gaya tidak seimbang yang terdapat pada sistem mesin rotasi. Perinsip mekanik yang terjadi adalah energi yang terbentuk pada sistem getaran akan didisipasi oleh fluida dalam bentuk perubahan energi dalam yang ditandai dengan meningkatnya temperatur fluida yang bersentuhan dengan permukaan benda padat dalam tingkat tertentu dapat mengubah efek viskositas fluida itu sendiri. Dalam kajian tertentu efek disipasi energi oleh fluida ini dapat dimanfaatkan untuk mengurangi respon getaran yang terjadi agar struktur yang bergetar dapat dikurangi respon dinamiknya, sehingga struktur dapat berumur lama.

Dengan pengurangan energi getaran melalui efek peredaman ini amplitudo getaran menjadi berkurang sesuai dengan parameter redaman yang didinginkan atau yang dirancang untuk pengurangan amplitudo getaran yang diinginkan. Mekanisme perubahan energi getaran menjadi energi panas dan bunyi dikenal dengan redaman. Peredam viscos diasumsikan tidak mempunyai massa dan elastisitas. Efek terbesar hanya diharapkan akan terjadi kecepatan relatif antara gerakan benda padat dengan fluida yang mempunyai viskositas tetertentu. Redaman viskos ini terjadi karena adanya gerakan ringan dengan dimensi tertentu bergerak relatif terhadap fluida yang menahan gerakan tersebut. Kita ketahui fluida tertentu mempunyai sifat khusus yaitu bersifat kental atau viskositas yang sulid berpisah satu sama lainnya dan sifat ini akan mempunyai efek seretan. Kekentalan atau viskositas ini adalah sarat mutlak suatu fluida dapat dijadikan sebagai peredaman sistem mesin rotasi. Beberapa peredam dapat menyerap getaran dan menggeser rentang frekuensi struktur utama.

Dalam operasi yang cukup lama mesin rotasi dapat mengalami perubahan respon getaran akibat beberapa peristiwa mekanik dan kelelahan struktur. Struktur yang sudah beroperasi tidak dapat diubah secara tiba-tiba hal ini dapat mengganggu proses. Salah satu yang bermanfaat untuk dilakukan adalah memasang redaman, yang dipasang pada tempat tertentu sehingga tidak akan 
memgaggu sistem yang sudah terpasang. Untuk memilih peredam yang cocok salah satunya adalah memilih dimensi peredam yang tidak menambah efek massa pada mesin rotasi. Beberapa kajian untuk mengurangi efek respon getaran pada putaran tertentu redaman akan dirancang bekerja pada rentang putaran tersebut dan tidak aktif pada putaran lain. Efek inilah yang banya dikembangkan dengan berbagai teknik dimana peredam dapat aktif bekerja dengan penambahan logaritma pengaturan aktif atu pasif. Peredam viskos untuk sistem mesin rotasi cocok dikembangkan untuk rotor berputar pada putaran tinggi. Salah satu sistem putaran tinggi adalah propeller pesawat terbang, baling-baling helikopter, turbin gas dan sejenisnya. Kajian terhadap sistem ini cocok untuk kasuskasus seperti di atas. Mode dan prosedur pegujian akan diarahkan untuk rotor dengan sifat tertentu dan peredam dengan dimensi tertentu.

\section{Ruang Lingkup Pembahasan}

Peredam dengan konstruksi yang dipasang pada satu poros dengan mesin rotasi kemudian fluida viskos dapat diganti dengan berbagai viskositas tertentu. Bentuk elemen redaman dengan efek tekanan yang dihasilkan oleh sudu lurus yang berputar pada tekan tertentu dan menahan gerakan poros-rotor akibat kekentalan fluida viskos yang bekerja. Seberapa besar efek penurunan amplitudo respon akan diteliti pada sistem ini.

\section{TINJAUAN PUSTAKA}

\section{Jenis-jenis redaman}

Jika terdapat gerakan relatif antara dua elemen yang bersentuhan yaitu salah satu elemen padat dengan elemen fluida yang berdekatan akan terjadi gerakan relatif antara lapisan fluida efek ini akan berlanjut bila putaran tidak dihentikan. Bila fluida yang bergerak relatif ini mengalami tekanan lebih dan tidak dapat dialirkan ini akan menimbulkan redaman viskos. Kedua dikenal dengan gesekan kering terjadi bila permukaan dua benda padat tidak dilumasi. Jenis gesekan yang ketiga dikenal dengan gesekan dalam, yaitu terjadi dalam satu jenis benda padat dimana mendapat gaya geser yang terkenal redaman histerisis.

\section{Fluida Viskos}

Kekentalan merupakan besaran yang sangat penting dalam menganalisis fuida bila bergerak relatif dengan benda padat. Fluida didefinisikan suatu zat yang tidak mampu menahan tegangan geser, fluida akan mengalami geseran dan mulai bergerak dengan laju regangan yang berbanding terbalik dengan koefesien kekentalan, $\mu$.

Pada umumnya fluid cenderung membasahi dinding silinder dan kecepatanya nol pada dinding silinder dan kondisinya lebih tinggi pada tengah silinder. Analogi ini identik dengan fluida yang mengalir pada pelat datar mempunyai kecepatan nol pada dasar pelat dan mempunyai kecepatan yang tinggi bila jauh dari pelat. Dari eksperimen menunjukan bahwa lapisan fluida berkontak dengan pelat yang bergerak mempunyai kecepatan sama dengan kecepatan pelat yang bergerak tersebut dan fluida berkontak dengan pelat diam akan tetap diam. Kecepatan fluida akan bervariasi dari nol sampai kecepatan $v$, pada elemem fluida kental, tegangan geser akan timbul dengan adanya perbedaan kecepatan $d u$ pada jarak $d y$. Perbedaan kecepatan ini menyebabkan distorsi diantara elemen fluida. Tegangan geser $\tau$ atau gaya geser persatuan luas berbanding lurus dengan gradien kecepatan, tegangan geser dapat didefinisikan sebagai berikut:

$$
\tau=\mu \frac{d u}{d y}
$$

Dimana $\mu$ adalah viskositas fluida, du elemen kecepatan sedangkan dy adalah elemen jarak. Dapat digambarkan pada Gambar 1 


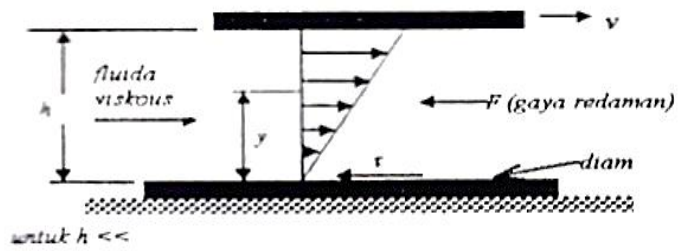

(a) 111

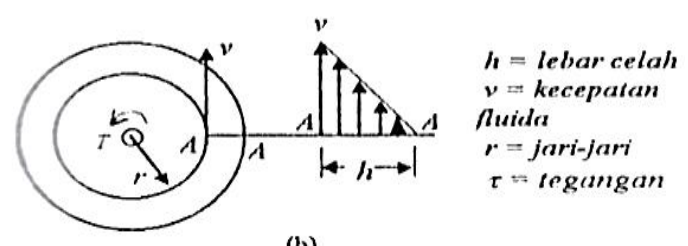

(b)

Gambar 1. Profil kecepatan dan gaya geser fluida antara pelat paralel dan fluida viskos

\section{Persamaan Koefesien Redaman Viskos Rotary}

Bentuk konstruksi redaman viskos rotary terdiri dari silinder yang dilengkapi dengan rotor berputar dan didalamnya terdapat celah yang berisi fluida. Fluida ini akan mendapatkan gesekan dan tekanan karena rotor yang dilengkapi dengan sudu-sudu berputar pada kecepatan tertentu. Torsi akan memutar rotor dengan kecepatan sudut tertentu dimensi silinder dengan tinngi $\mathrm{H}$ dan diameter D lebar celah fluida jauh lebih kecil dari jari-jari silinder $\mathrm{R}$ sebagai mana dapat dilihat pada Gambar 2.

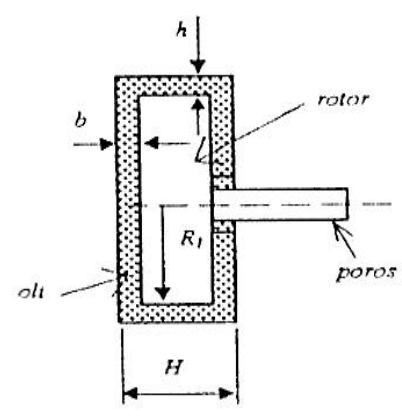

Tampak sisi samping

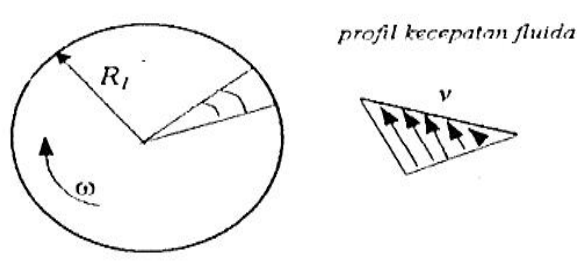

Gambar 2. Konstruksi peredam viskos rotary

Untuk menurunkan persamaan tersebut berlaku hubungan kesebandingan dimensi yaitu,

$\frac{d u}{d y}=\frac{V}{h}=\frac{R \omega}{h}$

Dimana $\omega$ adalah kecepatan sudut, sedangkan $\mathrm{V}$ adalah kecepatan tangensial rotor, $\mathrm{h}$ adalah lebar celah (lapisan film). Untuk menentukan gaya seret yang bekerja pada lapisan fluida, lapisan batas fluida yang menyebabkan terjadinya pergerakan fluida adalah,

$F_{t}=2 \pi R H \tau$ 
Untuk kasus dengan torsi maksimum berlaku hubungan untuk persamaan (1) yang kondisinya memenuhi pada persamaan (2)

$\tau=\mu \frac{R \omega}{h}$

Pada jari-jari maksimum gaya seret akan menghasikan pergerakan maksimum fluida efek ini menyebabkan fluida bergerak dengan kecepatan $\mathrm{V}$ tertentu,

$F_{t}=\frac{2 \pi \mu R^{2} H \omega}{h}$

Torsi yang terbentuk adalah perkalian gaya seret, $F_{t}$ dengan radius rotor, $\mathrm{R}$ yang berlaku pada celah sempit yang berisi fluida yang memenuhi persamaan berikut,

$T=\frac{2 \pi}{h} \mu \omega R^{3} H$

Tegangan geser akibat viskositas fluida yang terdapat disamping silinder bekerja sebesar

$\tau_{b}=\mu \frac{R \omega}{b}$

Elemen Torsi bekerja pada permukaan infinitesimal pada dasas silinder adalah :

$$
\begin{aligned}
d T_{b} & =\tau_{b}(r d \theta d r) r \\
& =\frac{\mu \omega}{b} r^{3} d r d \theta
\end{aligned}
$$

Torsi $T_{b}$ yang bekerja pada dasar silinder merupakan integral fungsi jari-jari dan sudut putar dari putaran poros sebagai berikut:

$T_{b}=\frac{\mu \omega}{b} \int_{0}^{2 \pi} \int_{0}^{R} R^{3} d r d \theta$

$=\frac{\pi}{2 b} \mu \omega R_{1}^{4}$ silinder:

Gaya $F_{b}$ yang bekerja pada samping silinder adalah tegangan geser dikali dengan luas tutup

$F_{b}=\frac{\mu \pi \omega R_{1}^{3}}{b}$

Torsi total yang bekerja jumlah dari persamaan (6) dan persamaan (9) yang dirubah menjadi persamaan berikut:

$$
\begin{aligned}
T_{\text {tot }} & =T+T_{b} \\
& =\frac{2 \pi}{h} \mu \omega R_{1}^{3} H+\frac{\pi}{2 b} \mu \omega R_{1}^{4} \\
& =\pi \mu \omega R_{1}^{3}\left(\frac{2 H}{h}+\frac{R}{2 b}\right)
\end{aligned}
$$

Besarnya daya yang dipindahkan dari energi gesekan ke media fluida sebagai energi dalam adalah torsi dikali kecepatan sudut poros: 


$$
\begin{aligned}
\mathrm{P} & =T_{t o t} \omega \\
& =\pi \mu \omega R_{1}^{3}\left(\frac{2 H}{h}+\frac{R}{2 b}\right) \quad . \omega \\
& =\pi \mu \omega^{2} R_{1}^{3}\left(\frac{2 H}{h}+\frac{R}{2 b}\right)
\end{aligned}
$$

Gaya total yang diperlukan untuk melawan gaya gesekan fluida pada permukaan rotor adalah

$$
\begin{aligned}
F_{\text {tot }}= & F_{1}+F_{b} \\
& =\mu \pi \omega R_{1}^{2}\left(\frac{2 H}{h}+\frac{R_{1}}{b}\right)
\end{aligned}
$$

Besarnya koefisien redaman yang terbentuk adalah sebanding dengan jumlah gaya yang bekerja dan berbanding terbalik dengan aliran fluida:

$c=\frac{F_{t o t}}{v}$

Bila kecepatan aliran fluida sebanding dengan kecepatan sudut rata-rata fluida akibat berputarnya piringan dalam dalam wadah redaman maka diperoleh

$v=\frac{\omega R_{1}}{2}$

Maka besarnya rasio redaman dalam persamaan (14) akan menghasikan bilangan yang memenuhi persamaan berikut:

$c=2 \pi \mu R_{1}\left(\frac{2 H}{h}+\frac{R_{1}}{b}\right)$

Persamaan ini berlaku untuk sistem dengan bilangan Reynolds

$R e=\rho \omega \frac{R_{1} h}{\mu}$

\section{Persamaan Sistem Getaran Mesin Rotasi}

Terdapatnya massa tidak seimbang pada pada komponen mesin rotasi akan menimbulkan gaya sentrifugal yang akan meyebabkan terjadinya sumber getaran. Gaya tidak seimbang dapat disebabkan oleh beberapa faktor diantaranya kepresisian mesin, material yang tak homogen dan kehausan pada berbagai komponen mesin akibat gesekan. Besarnya gaya sentrifugal yang terjadi sebanding dengan kwadrat kecepatan rotor, sehingga besarnya gaya sentrifugal dapat mencapai jauh lebih besar dari berat rotor itu sendiri.

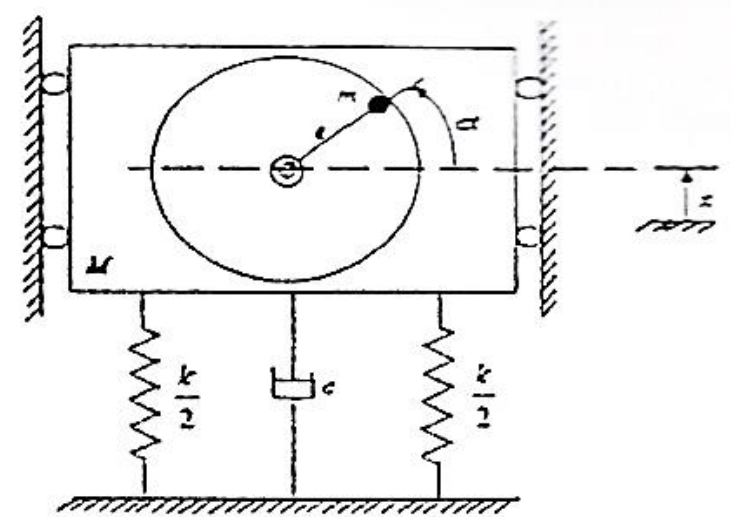

Gambar 3. Model getaran akibat massa tak seimbang 
Besanya gaya sentrifugal tersebut adalah,

$F=m e^{2}$

Pada Gambar (3) dapat terlihat besarnya simpangan yang timbul akibat gaya tak seimbang memenuhi persamaan berikut

$M x+c x+\ddot{k} \dot{x}=m e \omega^{2} \sin \omega t$

Dimana $\mathrm{M}$ adalah $\mathrm{m}, \mathrm{m}$ adalah massa tak seimbang c, redaman, $\mathrm{k}$ adalah kekakuan sistem sedangkan $\mathrm{x}, \dot{x}, \ddot{x}$, adalah perpindahan, kecepatan dan percepatan sistem yang berputar. Solusi keadaan tunak sistem tersebut adalah

$x(t)=X_{0} \sin (\omega t-\theta)$

Harga amplitudo simpangan pada keadaan tunak dapat dinyatakan dengan

$X_{0}=\frac{m e \omega^{2}}{\sqrt{\left(k-M \omega^{2}\right)^{2}+(c \omega)^{2}}}$

Sedangkan sudut phasa antara gaya pemicu dan simpangan sistem adalah

$\theta=\tan ^{-1}\left[\frac{c \omega}{k-M \omega^{2}}\right]$

Bila besaran di atas kita bentuk dalam besaran yang tidak berdimensi maka akan kita peroleh persamaan berikut:

$\frac{M X_{0}}{m e}=\frac{\left(\frac{\omega}{\omega_{n}}\right)^{2}}{\sqrt{\left[1-\left(\frac{\omega}{\omega_{n}}\right)^{2}\right]^{2}+\left[2 \zeta \frac{\omega}{\omega_{n}}\right]^{2}}}$

Dan beda phasa akan memenuhi persamaan berikut ini

$\theta=\tan ^{-1} \frac{2 \zeta\left(\frac{\omega}{\omega_{n}}\right)}{1-\left(\frac{\omega}{\omega_{n}}\right)^{2}}$

Sistem dalam persamaan (23) dan persamaan (24) dapat digambarkan sebagai sistem yang tanpa dimensi semua sistem getaran sistem poros rotor dapat memenuhi persamaan yang terdapat dalam kedua persamaan di atas. Sistem tersebut dapat kita gambarka pada Gambar 4.

\section{METODOLOGI}

\section{Batasan Alat Uji}

Penelitian penurunan amplitudo getaran pada mesin rotasi dengan peredam viscos dipengaruhi oleh beberapa faktor yaitu dimensi peredam dan jenis fluida peredam yang digunakan. Untuk mengetahui dengan pasti maka ditetapkan beberapa parameter sebagai berikut:

- Rotor 1, berdiameter $150 \mathrm{~mm}$, tebal $15 \mathrm{~mm}$ dan massa $1,9 \mathrm{~kg}$

- Rotor Peredam dengan 75 mm, tebal 15 mm dengan jumlah sudu 6 buah lurus dengan panjang sudu $15 \mathrm{~mm}$, masa rotor $0.25 \mathrm{~kg}$

- Motor listrik Penggerak 1/4 HP, putaran maksimum 1495 rpm

- Peredam dan media celah pemasukan dan pengeluaran fluida. 


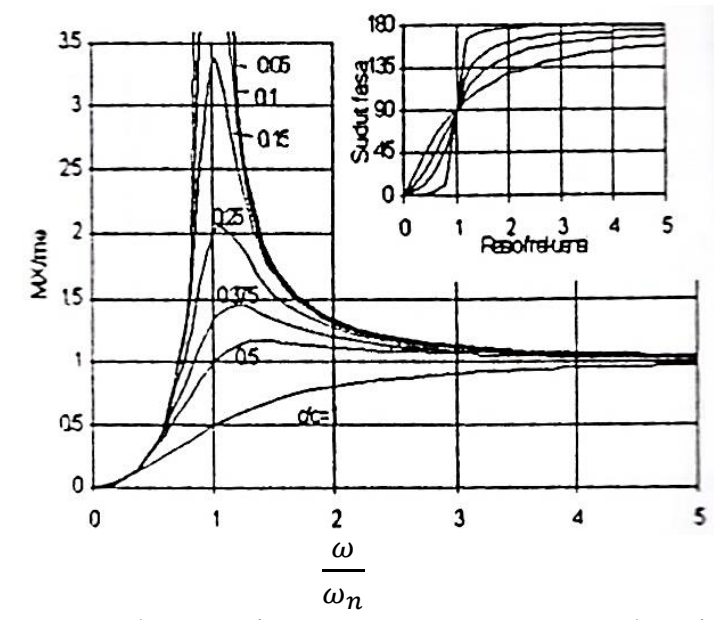

Gambar 4. Pengambaran sistem getaran massa tak seimbang tanpa dimensi

\section{Batasan Alat Uji}

Kendala yang dihadapi adalah sifat kelembaman (inersia) masing-masing komponen sistem mesin rotasi. Misalnya antara komponen listrik dan komponen mekanik keduanya mempunyai sifat kelembaman yang berbeda apakah masing-masing komponen masih mempunyai sifat analogi yang bersifat linear atau analoginya bersifat non linear terhadap kelembaman komponen. Seperti pada komponen mekanik luas penampang yang tidak linear akan sangat berpengaruh terhadap kelembaman sedangkan pada komponen listrik seperti tahanan sangat berpengaruh untuk mengurangi kecepatan respon yang diberikan. Elemen peredam berupa sebuah rumah (casing) dan didalamnya dapat ditempatkan sebuah rotor yang dihubungkan dengan sebuah poros yang berputardengan pengerak sebuah motor listrik. Diameter casing lebih besar dari diameter rotor peredam .diantara keduanya akan terdapat celah yang berisi fluida viskos. Untuk menjaga fluida viskos jangan merembes keluar dari casing perlu diberi sebuah seal. Asumsi-asumsi yang digunakan dalam penelitian adalah sebagai berikut:

- Temperatur fluida dianggap konstan

- Fluida memenuhi hukum fluida Newtonian

- Fluida incrompresibel

- Viskositas dipertahankan konstan selama pengujian

- Gaya inersia dan grafitasi diabaikan pada sistem

- Aliran fluida laminar

- Tidak ada slip antara fluida dan permukaan rotor.

- Putaran motor setiap pengujian divariabelkan.

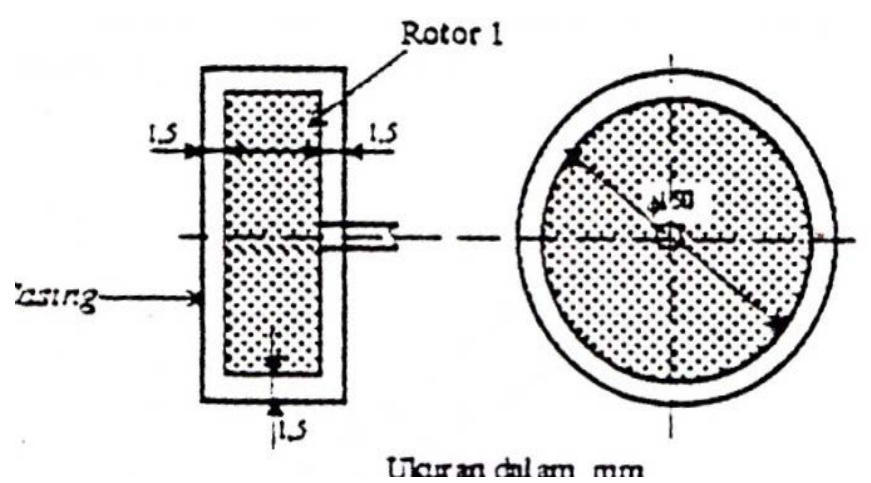

Gambar 5. Peredam Viskos

Benda yang dimodelkan untuk penelitian adalah struktur poros yang berbentuk memanjang dengan berbagai luas penampang yang tertentu sehingga tidak memberikan efek inersia yang 
berbeda. Tumpuan yang dipakai adalah pin yang berbentuk bulat dengan kelonggaran tertentu dimana dapat diberikan fluida pelumas dengan berbagai viskositas tertentu yang dapat memberikan efek peredaman tertetentu.

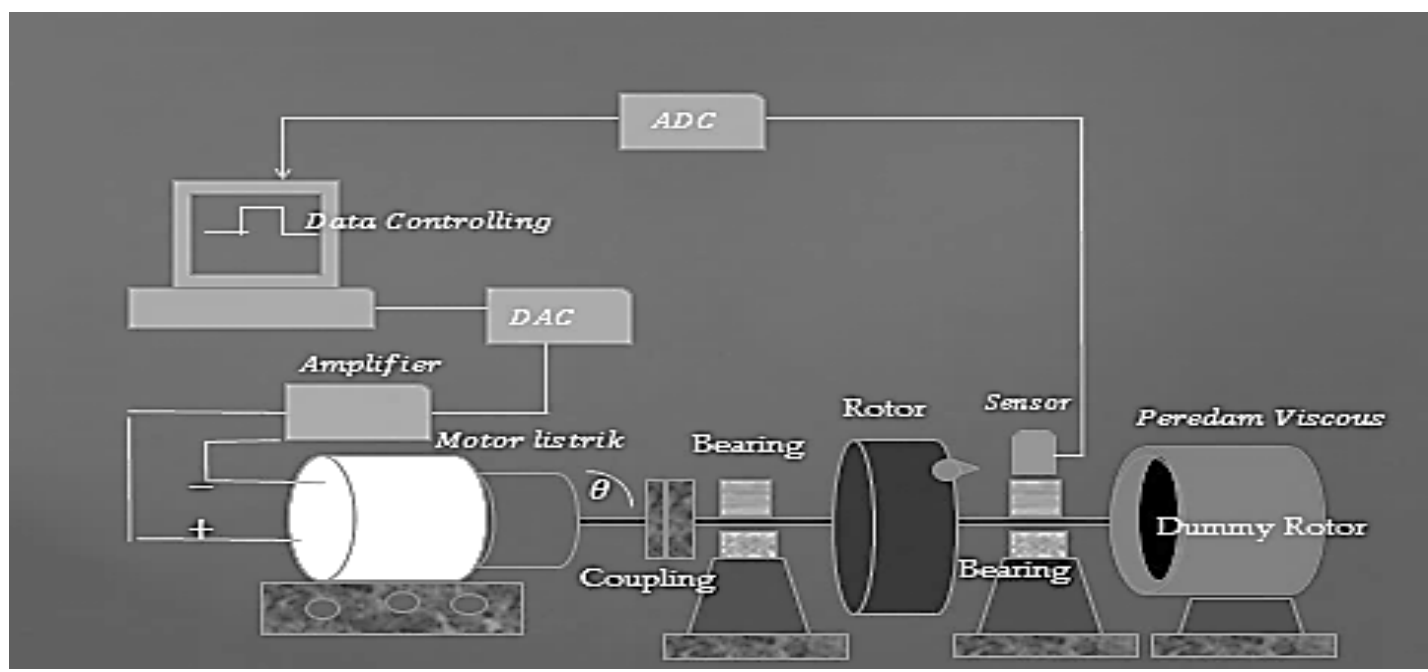

Gambar 6. Set-up pengujian poros-rotor dengan peredam viscous

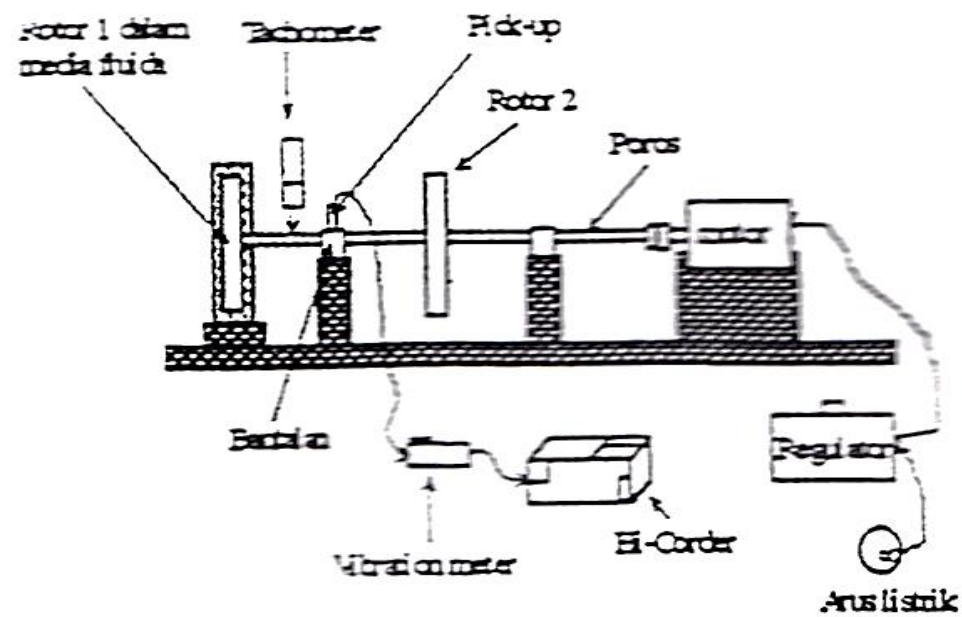

Gambar 7. Skematis penelitian peredam viscous untuk mesin rotasi

\section{Pengaruh Viscositas Peredam}

Pengaruh viscousitas oli peredam akan menentukan besarnya ketahanan yang menentukan efek tahan pada gerakkan batang.

Besar kecilnya inersia massa benda dapat mempengaruhi time respon suatu benda untuk bergerak. Sehingga posisi yang ditunjukkan juga dapat dipengaruhi. Bentuk geometri yang rumit serta pembebanan yang kompleks membuat perhitungan algoritma untuk menghitung inersia yang memberikan efek kelembabam harus memenuhi persyaratan matematik yang terjadi pada struktur kontinum.

Prinsip yang digunakan untuk menentukan inersia massa batang dengan penampang yang rumit adalah dengan metode elemen hingga dimana struktur dibagai menjadi elemen kecil yang saling berhubungan dengan titik-titik nodal elemen. Proses ini dikenal dengan diskritisasi elemen. Teknik ini adalah membagi struktur menjadi sejumlah elemen kecil dan elemen yang dipilih dapat segitiga, segi empat dan lain-lain. Bentuk elemen yang dipilih sangat mempengaruhi hasil perhitungan.

Redaman sangat berpengaruh terhadap posisi, karena mengadung efek menahan gerakan batang. Beberapa faktor yang menentukan perubahan redaman adalah luas penampang benda, 
viscositas pelumasan dan lebarnya celah pelumasan. Untuk kasus tertentu dimensi batang dan efek perubahan temperatur terhadap viscositas sangat mementukan efek redaman tang terjadi pada suatu pelumas. Oleh sebab itu pelumas dengan viscositas tertentu sangat berpengaruh pada time respon dari gerakan batang.

\section{HASIL DAN PEMBAHASAN \\ Hasil}

Untuk mentukan hal tersebut di atas besarnya redaman akan berpengaruh terhadap efek gerakan benda. Untuk mengetahui hal tersebut di atas perlu mengkaji lebih dalam besarnya efek redaman tersebut. Pada Gambar 8 dan Gambar 9. dapat kita lihat penurunan amplitudo respon getaran sistem poros rotor untuk jenis peredam dengan material fluida:

- Peredam Oli jenis SAE $10 \mathrm{~W}=0.0341 \mathrm{~Pa}$.s dengan damping rasio $\zeta=0.1$.

- Peredam Oli jenis SAE $40 \mathrm{~W}=0.0126 \mathrm{~Pa}$.s dengan damping rasio $\zeta=0.5$.

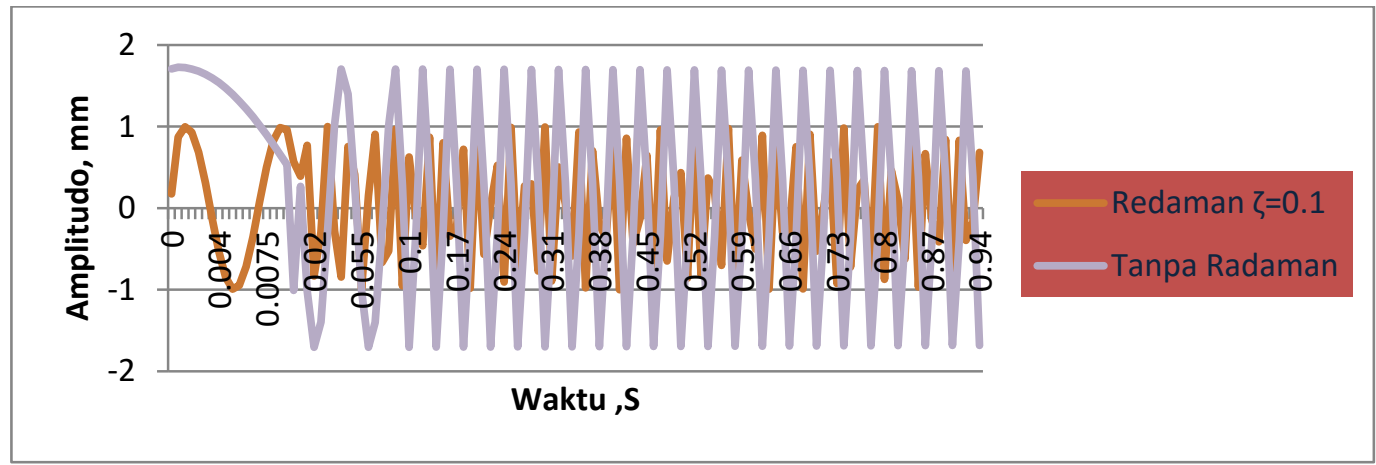

Gambar 8. Grafik peluruhan domain waktu poros-rotor dengan gain $\zeta=0.1$

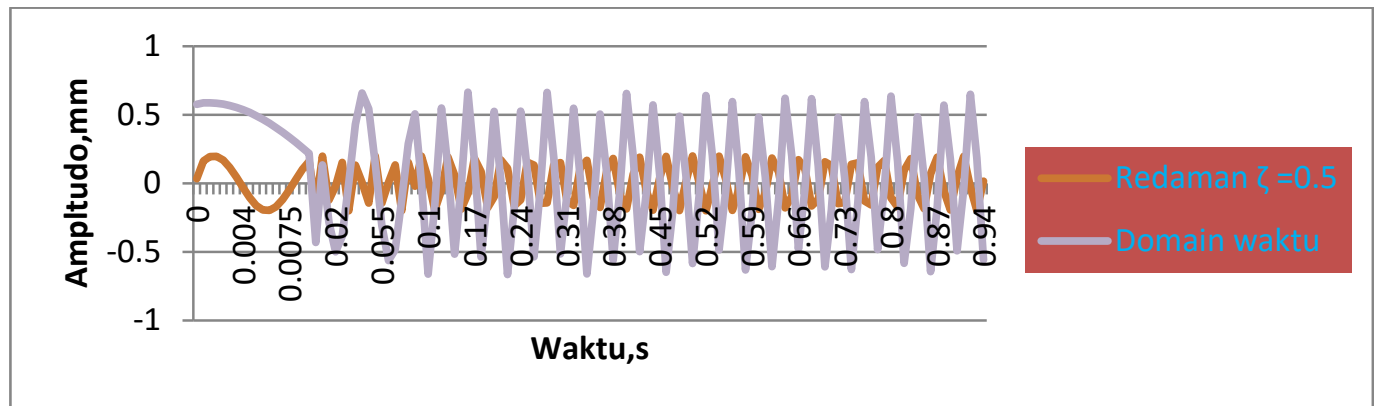

Gambar 9. Grafik peluruhan domain waktu poros-rotor dengan gain $\zeta=0.5$

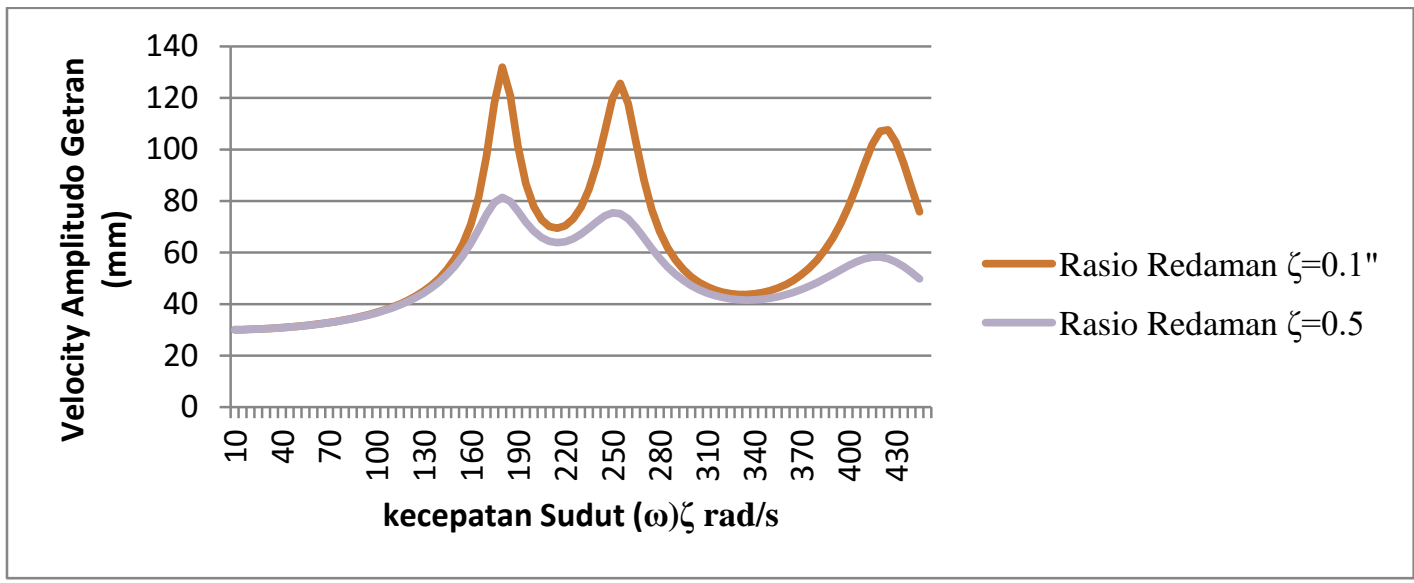

Gambar 10. Grafik peluruhan domain frekuensi poros-rotor 


\section{Pembahasan:}

- Pada Gambar 8 dapat kita lihat bahwa untuk harga penurunan amplitudo respon dapat dikurangi hingga 30\% untuk rasio redaman $\zeta$ adalah 0.1. Dari hasil tersebut Pemakaian pelumas untuk cairan peredam viskos dapat mengurangi amplitudo sistem. Untuk frekuensi pribadi sistem dengan harga putaran kritis harga $\omega_{d}=180.62 \frac{\mathrm{rad}}{\mathrm{s}} \cdot \omega_{d}=255.34 \frac{\mathrm{rad}}{\mathrm{s}} \cdot \omega_{d}=424.86 \frac{\mathrm{rad}}{\mathrm{s}}$.

- Pada Gambar 9 dapat kita lihat bahwa untuk harga penurunan amplitudo respon dapat dikurangi hingga 60\% untuk rasio redaman $\zeta$ adalah 0.5. Dari hasil tersebut Pemakaian oli pelumas untuk cairan peredam viskos dapat mengurangi amplitudo sistem. Untuk frekuensi pribadi sistem dengan harga putaran kritis harga $\omega_{d}=180.62 \frac{\mathrm{rad}}{\mathrm{s}} \cdot \omega_{d}=255.34 \frac{\mathrm{rad}}{\mathrm{s}} \cdot \omega_{d}=424.86 \frac{\mathrm{rad}}{\mathrm{s}}$.

\section{DAFTAR PUSTAKA}

[1]. Subrata, Ganda, "Korelasi Hasil Kaji Teoritik dan Eksperimental Getaran Pelat Model T', Tugas Sarjana S2, ITB, 1990.

[2]. Setyanto, Djoko, "Kaji Teoritik dan Eksperimental Perilaku dinamik Bodi Mobil Daihatsu Zebra, Tugas Sarjana, S2 ITB, 1992.

[3]. Eddy, Noor,” Pengukuran Fungsi Transper dan Model Elemn Hinggauntuk Analisis Dinamik Body Mobil, Tugas Sarjan , S2, ITB, 1992

[4]. Sumendap, Fredy Robin, "Kaji Perbandingan Metode Curve Fitting dengan redaman Viscous Proprtional dan Redaman Kasus Umum”, Tugas Sarjana, S1, ITB, 1991

[5]. Nusyirwan, "Penggunaan Parameter Modus Getar Untuk Analisis Sensitifitas Struktur Mekanik”, Tugas Sarjana, S2, ITB, 1995.

[6]. Nusyirwan, "Kaji Teoritik Frekuensi Pribadi dan Modus Getar Silinder Berdinding Tipis dengan Metode Geometri”, Jurnal Teknika, No.34 Vol I THN XVII, Fakultas Teknik Universitas Andalas, 2010. 